\title{
PENINGKATAN KEMAMPUAN GURU DALAM PEMBELAJARAN DARING MENGGUNAKAN GOOGLE CLASSROOM
}

\author{
Marlya Fatira AK ${ }^{1 \Xi}$, Emmy Syafitri², Rahmi Ramadhani ${ }^{3}$, Mesran ${ }^{4}$ \\ Politeknik Negeri Medan ${ }^{1}$, Universitas Dharmawangsa ${ }^{2}$, Universitas Potensi Utama ${ }^{3}$, Universitas Budi \\ Dharma $^{4}$

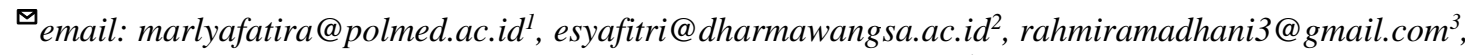 \\ mesran.skom.mkom@gmail.com ${ }^{4}$
}

\begin{abstract}
This community service activity aims to optimize teachers' role as real learners in providing online learning materials using google classroom. Al Munadi Integrated Islamic Elementary School as partner, located at Medan City, North Sumatra. The problems found that teachers often experience difficulties in implementing online learning due to the lack of teacher knowledge in the use of technology in the fo learning media, using google classroom. This condition makes students not maximally get learning from the teacher and tends to have more time spent on students who are in elementary school-age relaxing and playing, not learning because activities are carried out at home, and learning materials are minimal. The Method are survey, observation, and interview activities to collect initial data. This activity carried out through training, education, and information delivery activities in the form of training on the use of google classroom for online learning. All the features in Google Classroom are taught to teachers through these training activities. The service team pays attention to and accompanies the trainee teachers on the day of implementing the action, directs and assists teachers as training participants to follow the direction of the resource person. The training materials delivered related to google classroom are Managing classes, Creating Classes, Inviting students to enter classes, delivering materials in google classroom, communicating with students via google classroom, delivering material in the form of files, videos, and links to students through Google Classroom, making exam questions, quizzes and assignments in Google Classrooms and doing face-to-face using Google Meet. Increasing the Ability of Teachers in Online Learning Using Google Classroom at SDIT Al Munadi Medan has now been achieved by implementing training activities with positive responses and teachers' understanding of the material presented, reaching an average of $91.94 \%$ of the 35 teacher participants who attended the training.
\end{abstract}

Keywords-- Google Classroom, Teknologi, Pembelajaran Daring, Guru Pembelajar

\begin{abstract}
Abstrak
Kegiatan pengabdian ini bertujuan untuk mengoptimalkan peran guru sebagai pembelajar sejati dalam memberikan materi pembelajaran secara daring menggunakan google classroom. Mitra pada program Pengabdian ini adalah Sekolah Sekolah Dasar Islam Terpadu Al Munadi yang berlokasi di Gg. Tribakti, Tanah Enam Ratus, Kec. Medan Marelan, Kota Medan, Sumatera Utara. Permasalahan yang ditemukan para guru sering mengalami kesulitan dalam melaksanakan pembelajaran secara daring dikarenakan masih minimnya pengetahuan guru dalam pemanfaatan tekhnologi berupa media pembelajaran daring salah satunya menggunakan google classroom. Kondisi ini menjadikan peserta didik, tidak maksimal memperoleh pembelajaran dari Guru dan cenderung waktu yang dimiliki peserta didik yang berada di usia sekolah dasar lebih banyak terbuang untuk ber santai dan bermain, bukan belajar karena kegiatan dilakukan dirumah dan materi belajar sangat minim. Tim pelaksana Pengabdian melakukan kegiatan survey, observasi, dan wawancara untuk mengumpulkan data awal. Kemudian pelaksanaan kegiatan pengabdian dilakuan melalui kegiatan pelatihan, edukasi dan penyampaian informasi berupa pelatihan penggunaan google classroom untuk pembelajaran daring. Semua fitur yang ada di Google Classroom diajarkan kepada guru melalui kegiatan pelatihan tersebut. Tim pengabdian memperhatikan dan mendapingi guru peserta pelatihan dihari pelaksanaan kegiatan, mengarahkan dan membantu guru sebagai peserta pelatihan untuk mengikuti arahan dari narasumber. Materi pelatihan yang diampaikan terkait google classroom adalah: Mengelola kelas dengan menggunakan google classroom, Membuat Kelas di Google Classroom, Mengundang Murid masuk ke kelas, menyampaikan materi di google classroom, melakukan komunikasi dengan murid melalui google classroom, menyampaikan materi dalam bentuk file, video, dan link kepada murid melalui google classroom, membuat soal ujian, kuis dan tugas di google classroom serta melakukan tatap muka langsung menggunakan google meet. Peningkatan Kemampuan Guru Dalam Pembelajaran Daring Menggunakan Google Classroom di SDIT Al Munadi
\end{abstract}


Medan kini telah tercapai melalui pelaksanaan kegiatan pelatihan dengan Tanggapan positif dan pemahaman guru terhadap materi yang disampaikan mencapai rerata $91,94 \%$ dari 35 peserta guru yang hadir mengikuti pelatihan.

Kata Kunci-- Google Classroom, Teknologi, Pembelajaran Daring, Guru Pembelajar

\section{Pendahuluan}

Guru merupakan pembelajar sejati. Tugasnya menjadikan jabatan guru sebagai jabatan yang mulia dalam berbagai kondisi kehidupan yang ada. Guru menjadi penentu masa depan generasi sebuah bangsa. Di pundak Gurulah peran dalam menciptakan sumber daya manusia yang baik dan berkompeten diberikan agar tercipta bangsa yang ber taqwa, cerdas, kuat dan bermartabat. Kondisi ini diamanatkan dalam Undang-undang Nomor 14 tahun 2005, menyatakan bahwa guru merupakan tenaga profesional yang mempunyai fungsi, peran, dan kedudukan yang sangat penting dalam mencapai visi pendidikan 2025 yaitu menciptakan insan Indonesia cerdas dan kompetitif. Pernyataan tersebut menjadikan suatu keharusan bagi seorang guru untuk terus menerus belajar, beradaptasi dengan perkembangan ilmu pengetahuan dan teknologi yang terjadi dalam berbagai keadaan zaman.

Zaman yang terus berkembang mengikuti perkembangan kecerdasan manusia dalam mamanfaatkan tekhnologi menjadikan perubahan dan adaptasi menjadi suatu keniscayaan yang abadi. Perubahan ini yang terus perlu diikuti semua makhluk di dunia bila tetap ingin ada dan bertahan. Perubahan kehidupan ke arah new normal karena kondisi Pandemi Covid 19 yang dihadapi Indonesia dan negara umumnya di dunia saat ini merupakan salah satu penyesuaian kehidupan yang perlu dilakukan. Termasuk penyesuaian kehidupan dalam kegiatan Pendidikan di sekolah yang dilakukan oleh guru dan murid secara konvensional, kini diminta untuk dilakukan secara daring (pembelajaran jarak jauh).

Wabah Coronavirus merupakan kelompok virus yang menyebabkan penyakit mulai dari gejala ringan sampai berat. Coronavirus Diseases 2019 (COVID19) merupakan jenis penyakit jenis baru, belum pernah diidentifikasi sebelumnya pada manusia. Sejak 30 Januari 2020 WHO telah menetapkan sebagai kedaruratan kesehatan masyarakat yang meresahkan dunia. Pada tanggal 2 Maret 2020, Indonesia melaporkan kasus konfirmasi COVID19 sebanyak 2 kasus. Saat ini, 4 Oktober 2020 berdasarkan data Tim Komunikasi Komite Penanganan Corona Virus Disease 2019 (Covid-19) dan Pemulihan Ekonomi Nasional tercatat jumlah penduduk Indonesia yang meninggal karena Covid 19 mencapai 11.151 kasus (https://covid19.go.id/p/berita/kesembu han-kumulatif-mencapai-228453-

kasus)

Jumlah kasus Covid 19 yang terus meningkat ini menjadikan imbas yang terjadi pada berbagai aspek kehidupan, baik sosial, ekonomi, pariwisata dan pendidikan. Surat Edaran (SE) yang dikeluarkan pemerintah pada 18 Maret 2020 segala kegiatan didalam dan diluar ruangan di semua sektor sementara waktu ditunda demi mengurangi penyebaran corona terutama pada bidang pendidikan. Pada tanggal 24 maret 2020 Menteri Pendidikan dan Kebudayaan Republik Indonesia mengeluarkan Surat Edaran Nomor 4 Tahun 2020 Tentang Pelaksanaan Kebijakan Pendidikan Dalam Masa Darurat Penyebaran COVID, dalam Surat Edaran tersebut dijelaskan bahwa proses belajar dilaksanakan di rumah melalui pembelajaran daring/jarak jauh 
dilaksanakan untuk memberikan pengalaman belajar yang bermakna bagi siswa. Belajar di rumah dapat difokuskan pada pendidikan kecakapan hidup antara lain mengenai pandemi Covid-19.

Memperhatikan adanya surat edaran tersebut, praktis semua sekolah dibawah pengelolaan Kementerian Pendidikan harus mengikuti peraturan yang telah dikeluarkan. Kondisi ini menjadikan semua dilakukan secara mendadak, tiba-tiba tanpa persiapan, sehingga secara umum timbul kondisi belajar yang capaiannya tidak ideal seperti yang telah direncanakan. Banyak faktor yang menyebabkannya antara lain adalah kondisi sekolah, kondisi guru, kondisi peserta didik, kondisi orang tua murid, dan faktor geografis lingkungan dan ketersediaan akses internet pun menjadi faktor penentu lainnya. Hal ini senada dengan yang disampaikan oleh Nakayama M, Yamamoto (2007) bahwa pembelajaran ini merupakan inovasi pendidikan untuk menjawab tantangan akan ketersediaan sumber belajar yang variatif. Keberhasilan dari suatu model ataupun media pembelajaran tergantung dari karakteristik peserta didiknya. Dari semua literatur dalam elearning mengindikasikan bahwa tidak semua peserta didik akan sukses dalam pembelajaran online. Ini dikarenakan faktor lingkungan belajar dan karakteristik peserta didik.

Berbagai keadaan tersebut mencerminkan bahwa penyesuaian dan adaptasi terhadap kondisi menjadi suatu hal yang perlu disegerakan. Hal ini lah yang dilakukan oleh Sekolah Dasar Islam Terpadu Al Munadi. Sekolah Dasar Islam Terpadu Al Munadi yang berlokasi di Gg. Tribakti, Tanah Enam Ratus, Kec. Medan Marelan, Kota Medan, Sumatera Utara 20244 melakukan penyesuaian terhadap cara belajar di masa Pandemi Covid 19. Beradasarkan wawancara yang dilakukan pada Kepala Sekolah SDIT Al
Munadi pada 29 Agustus 2020, diketahui bahwa jumlah guru SD yang terdaftar di sekolah ada 45 orang. Jumlah ini sudah gabungan antara guru bidang umum, guru tahfiz maupun guru tetap sekolah. Keseluruhan guru tersebut terlibat dalam kegiatan pembelajaran yang dilakukan secara daring, sejak Maret 2020.

Diceritakan Kepala sekolah bahwa banyak kendala yang dialami guru ketika melakukan pembelajaran secara daring. Permasalahan secara umum dapat dilihat dari sisi sekolah maupun dari sisi peserta didik. Permasalahan dari sisi sekolah salah satunya adalah keterbatasan kemampuan guru dalam memanfaatkan teknologi pembelajaran di era digital. Guru yang terbiasa melakukan proses belajar mengajar secara tatap muka langsung kepada peserta didik dengan memanfaatkan fasilitas sekolah kini diminta untuk menggunakan telepon, whatsap, video, internet, google classroom. Kondisi ini sangat membuat sebagian besar guru kesulitan beradaptasi. Apalagi media-media tersebut belum familiar bagi mereka.

Kondisi minim pengetahuan terhadap pemanfaatan tekhnologi pembelajaran bagi guru tentu akan menjadi kendala dalam jangka panjang bila tidak diatasi, oleh karena itu Tim pengabdian masyarakat yang terdiri dari dosen-dosen dalam Forum Kerja Sama Perguruan Tinggi (FKPT) di Sumatera Utara hadir ke Sekolah SDIT Al Munadi untuk memberikan pendampingan dan pelatihan bagi guru-guru untuk memanfaatkan tekhnologi dalam pembelajaran daring dengan menggunakan google Classroom. Tujuan dari kegiatan pengabdian ini tentunya adalah setelah memperoleh pelatihan dan pendampingan dalam penggunaan Google Classroom sebagai media pembelajaran daring, maka guruguru SDIT Al Munadi menjadi lebih terampil, dan lebih mudah mengelola kelas, melakukan share materi pengajaran, mudah berinteraksi dengan 
murid melalui google classroom. Tujuan akhirnya pembelajaran daring yang menyenangkan dan efektif untuk anak sekolah dasar dapat tercapai.

\section{Metode Pengabdian}

Program Pengabdian kemitraan masyarakat ini dilakukan dengan mengumpulkan data deskriptif dan kualitatif yang kemudian dianalisis dan diproses guna menghasilkan solusi untuk permasalahan yang dihadapi mitra. Dalam Pelaksanaan PKM ini digunakan metode sebagai berikut:

\section{Teknik Pengumpulan Data}

Pengumpulan data dilakukan melalui wawancara kepada Kepala SD IT AlMunadi, H. Muhammad Sairin, S.Ag., sehingga diperoleh informasi mengenai keadaan sekolah dan guru di SD IT AlMunadi. Kesulitan dan kendala yang dihadapi oleh sekolah dan guru selama menjalani pembelajaran daring di masa Pandemi Covid 19 ini.

\section{Teknik Analisa Data}

Setelah data dikumpulkan kemudian dilakukan tahap Analisa terhadap data yang ada. Analisa dilakukan secara deskriftif dan disajikan dalam bentuk tabel, grafik dan penjelasan. Tahap selanjutnya adalah membuat materi pelatihan dan modul untuk memberikan pelatihan, pemahaman dan edukasi kepada guru sesuai kebutuhannya yaitu pelatihan pemanfaatan google classroom untuk kegiatan pembelajaran. Untuk mengukur keberhasilan kegiatan pelatihan, maka sebelum dan setelah kegiatan pelatihan diberikan kuisioner kepada peserta (dalam hal ini guru SDIT Al Munadi).

Gambar 1 berikut ini menunjukkan diagram alir prosedur kerja untuk mendukung realisisasi metode yang ditawarkan pada kegiatan pengabdian adalah:

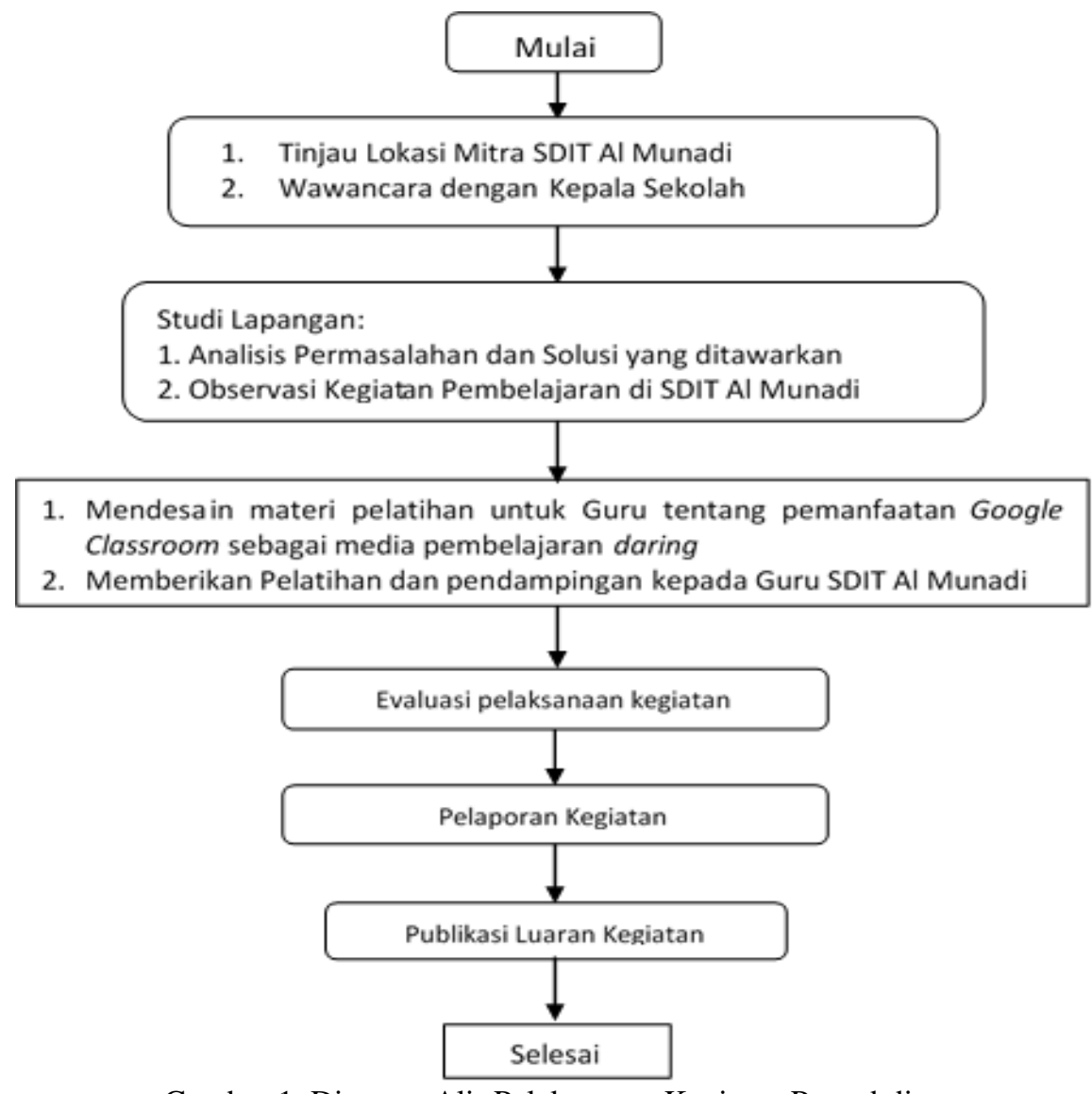

Gambar 1. Diagram Alir Pelaksanaan Kegiatan Pengabdian 
Kegiatan Pengabdian ini diawali dengan melakukan kunjungan ke lokasi mitra, melakukan wawancara pada Kepala Sekolah SDIT Al Munadi. Setelah semua informasi tentang mitra diperoleh maka dilakukanlah diskusi atas perencanaan solusi atas permasalahan yang dihadapi mitra, diikuti dengan implementasi dan sosialisasi serta validasi terhadap solusi yang ditawarkan Tim pengabdian dosen FKPT.

1. Tahap awalan/persiapan

a. Mengidentifikasi kondisi Sekolah dan guru SDIT Al Munadi

b. Menetapkan bentuk kegiatan yang akan dilakukan di sekolah SDIT Al Munadi

2. Tahap Pelaksanaan

Pelatihan dan pendampingan pemanfaatan Google Classroom untuk pembelajaran daring bagi guru SDIT Al Munadi

3. Tahap pengakhiran

a. Evaluasi pencapaian dan manfaat pelatihan yang telah diterima oleh guru SDIT Al Munadi

b. Publikasi hasil pengabdian kepada masyarakat pada media massa melalui website FKPT

c. Publikasi kegiatan pengabdian kepada masyarakat sebagai luaran tambahan pada Jurnal Nasional terkareditasi SINTA.

\section{Hasil Dan Pembahasan}

Memperhatikan tahapan pelaksanaan kegiatan pengabdian masyarakat yang telah direncankan sebelumnya maka dilakukanlah kegiatan pengabdian pada Hari Kamis, 29 Agustu2 2020. Kegiatan Pengabdian masyarakat dilakukan di lokasi sekolah SDIT Al Munadi berlokasi di Gg. Tribakti, Tanah Enam Ratus, Kec. Medan Marelan, Kota Medan, Sumatera Utara 20244. Dalam kegiatan pengabdian tersebut, dilakukan kegiatan pelatihan dengan narasumber dosen Forum Kerjasama Perguruan
Tinggi. Materi pelatihan yang diampaikan terkait google classroom adalah: Mengelola kelas dengan menggunakan google classroom, Membuat Kelas di Google Classroom, Mengundang Murid masuk ke kelas, menyampaikan materi di google classroom, melakukan komunikasi dengan murid melalui google classroom, menyampaikan materi dalam bentuk file, video, dan link kepada murid melalui google classroom, membuat soal ujian, kuis dan tugas di google classroom serta melakukan tatap muka langsung menggunakan google meet.

Kegiatan Pelatihan diberikan kepada 35 orang guru yang hadir, dari berbagai disiplin ilmu dan bidang studi. Setelah dilakukan evaluasi terhadap pelaksanaan kegiatan pelatihan maka diketahui bahwa:

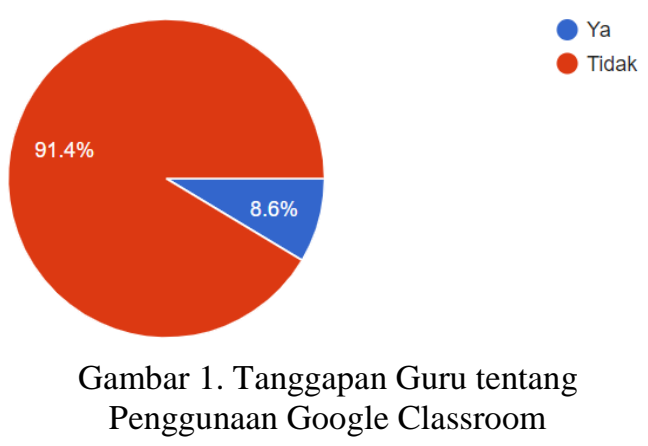

Sebelum memperoleh pemahaman tentang Google Classroom, 91,4\% guru SD IT Al Munadi tidak mengenal Google Classroom, dan menyatakan tidak menggunakan Google Classroom dalam pemebalajaran daring.

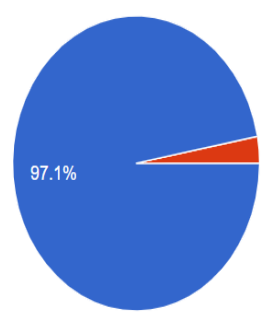

- Benar

Gambar 2. Tanggapan Guru Mengenai Menghubungkan Murid di Google Classroom 
Setelah pelaksanaan kegiatan pelatihan, dan guru mendapatkan pemahaman tentang pemanfaatan google classroom terlihat bahwa Guru SDIT Al Munadi mayoritas $(7,1 \%$ kini telah mampu membuat kelas di Google Classroom dan telah mampu menghubungkan murid untuk masuk ke kelasnya. Hanya 2,9\% guru yang belum berhasil membuat kelas dan belum berhasil mengundang murid untuk masuk ke kelasnya. Hal ini disebabkan karena ketiadaan perangkat yang dimiliki oleh guru saat pelaksanaan pelatihan.

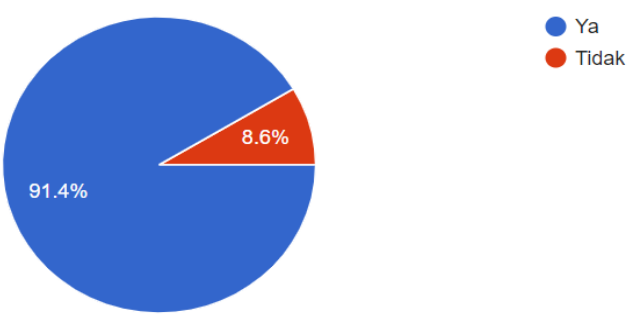

Gambar 3. Tanggapan Guru Mengenai Membuat Daftar Hadir

di Google Classroom setelah pelatihan

Setelah pelaksanaan kegiatan pelatihan, dan guru mendapatkan pemahaman tentang pemanfaatan google classroom terlihat bahwa Guru SDIT Al Munadi mayoritas telah mampu Membuat Daftar Hadir di Google Classroom. Hal ini dinyatakan oleh $91,4 \%$ guru, hanya $8,6 \%$ yang menyatakan belum mengetahui.

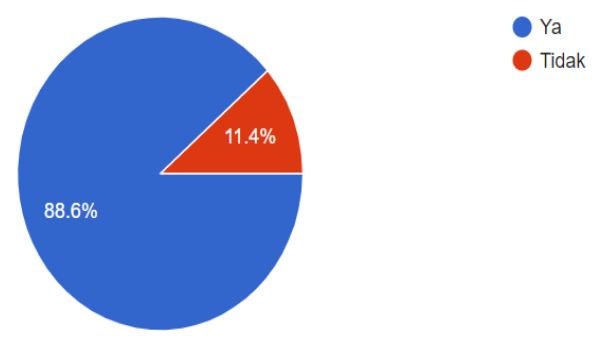

Gambar 4. Tanggapan Guru Mengenai Google Classroom setelah pelatihan

Setelah pelaksanaan kegiatan pelatihan, dan guru mendapatkan pemahaman tentang pemanfaatan google classroom terlihat bahwa Guru SDIT Al Munadi mayoritas telah mampu mengirimkan vidio pembelajaran melalui Google Classroom. Hal ini dinyatakan oleh $88,6 \%$ guru, hanya $11,4 \%$ yang menyatakan belum mengetahui.

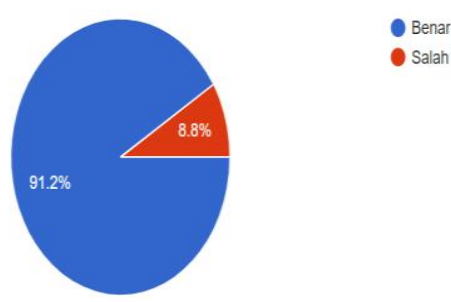

Gambar 5. Tanggapan Guru Mengenai meberikan penilaian

melalui Google Classroom setelah pelatihan

Setelah pelaksanaan kegiatan pelatihan, dan guru mendapatkan pemahaman tentang memberikan penilaian secara langsung terhadap tugas murid melalui google classroom. Terlihat bahwa Guru SDIT Al Munadi mayoritas (91,2\%) telah mampu menilai hasil pekerjaan muridnya, dan $8,8 \%$ yang menyatakan beum menguasai cara meinilai melalui Google Classroom.

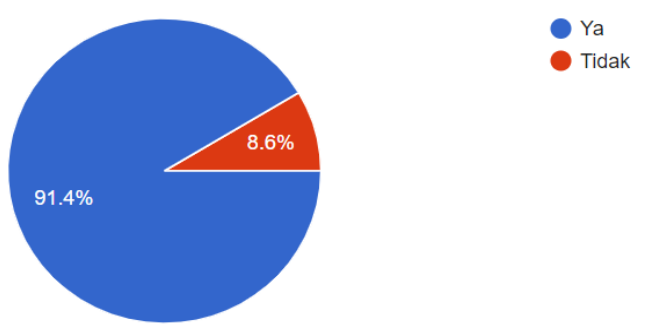

Gambar 6. Tanggapan Guru Mengenai Pantauan Kepala Sekolah dalam pembelajaran melalui Google Classroom setelah pelatihan

Setelah pelaksanaan kegiatan pelatihan, dan guru meyakini bahwa dengan fasilitas Google Classroom, maka Kepala sekolah akan lebih mudah melakukan pemantauan setiap kelas yag diajarkan oleh guru. Hal ini dinayatakn oleh mayoritas guru yaitu sebanyak 91,4\%. Sedangkan sisanya $8,6 \%$ menyakan tidak mengetahui mengenai hal tersebut. 
Berdasarkan pelaksanaan kegiatan pengabdian ini telaihat bahwa setelah memperoleh pelatihan google classroom, guru SD IT Al Munadi kini telah memahami dengan baik penggunaan Google Classroom. Dan meyakini bahwa penggunaan google classroom akan mempermudah pelaksanaan pembelajaran secara daring ke depannya di sekolah SDIT AL Munadi.

\section{Kesimpulan}

Peningkatan Kemampuan Guru Dalam Pembelajaran Daring Menggunakan Google Classroom di SDIT Al Munadi Medan kini telah tercapai melalui pelaksanaan kegiatan pelatihan dengan tanggapan positif dan pemahaman guru terhadap materi yang disampaikan mencapai rerata $91,94 \%$ dari 35 peserta guru yang hadir mengikuti pelatihan.

Sebagai saran diharapkan kegiatan pelatihan kepada guru untuk peningkatkan kemampuan guru dalam memanfaatkan teknologi untuk pembelajaran daring dapat dilakuan secara continue setiap bulan atau dua bulan sekalli sehingga kompetensi dan keterampilan guru untuk beradaptasi dengan tekhnologi akan semakin baik dan pembelajaran pun akan lebih mudah dan menarik dilakukan.

\section{Ucapan Terima Kasih}

Ucapan terima kasih tim pengabdian ucapkan kepada Ketua FKPT Bapak Mesran, M.Kom. serta Kepala SD IT Al-Munadi, H. Muhammad Sairin, S.Ag. yang telah memfasilitasi pelaksanaan kegiatan pengabdian masyarakat ini. Serta kepada seluruh dosen pelaksana kegiatan pengabdian di SDIT Al Munadi yang telah mendanai secara mandiri program pengabdian masyarakat ini, serta tim ucapkan terimakasih seluruh guru peserta pelatihan di SDIT Al Munadi yang telah berkenan hadir dari awal sehingga berakhimya pelaksanaan pelatihan.

\section{Daftar Pustaka}

[1] Dewi, Wahyu Aji Fatma. 2020. Dampak Covid-19 Terhadap Implementasi Pembelajaran Daring Di Sekolah Dasar. Edukatif : Jurnal Ilmu Pendidikan Volume 2 Nomor 1 April 2020 Halm 55-61. Jakarta: Universitas Kristen Satya Wacana

[2] Menteri Pendidikan. 2020. Surat Edaran Nomor 3 Tahun 2020 Tentang Pelaksanaan Pendidikan dalam Masa Darurat CoronaVirus (COVID-19).

[3] Nakayama M, Yamamoto $H, \&$ S. R. (2007). The Impact of Learner Characterics on Learning Performance in Hybrid Courses among Japanese Students. Elektronic Journal ELearning, Vol.5(3).1

[4] Sugiyono. 2012. Metode Penelitian Kuantitatif Kualitatif dan R\&D. Alfabeta.

[5] Wicaksono, V. D., \& Rachmadyanti, P. 2016. Pembelajaran Blended Learning melalui Google Classroom di Sekolah Dasar. Seminar Nasional Pendidikan PGSD UMS \& HDPGSDI Wilayah Timur.

[6] http://www.seminar-id.com/berita954-forum-kerjasama-pendidikantinggi-langsungkan-kegiatanpengabdian-kepada-masyarakat-disd-it-almunadi.html

[7] https://covid19.go.id/p/berita/kesem buhan-kumulatif-mencapai228453-kasus. 
